\title{
PLURALISME HUKUM ISLAM, SEBUAH PEMBACAAN AWAL
}

\author{
Oleh \\ Benni Setiawan
}

\begin{abstract}
Abstrak
Pluralisme meniscayakan adanya kesediaan antarpemeluk agama dan keagamaan untuk berdialog, saling berbicara, dan saling mendengar. Dialog yang dikembangkan bukan semata dialog teologi, tetapi juga dialog kehidupan, dialog kegiatan sosial, berbagi pengalaman keagamaan, dan do'a bersama. Hukum Islam berdiri di atas prinsip-prinsip yang harus dipertahankan secara absolut dan universal. Prinsip-prinsip tersebut adalah ajaran yang qath'i dan menjadi tolok ukur pemahaman dan penerimaan hukum Islam secara keseluruhan. Pluralisme hukum Islam (Islamic legal pluralism) penting dibahas untuk memberikan gambaran yang jelas mengenai makna dan interpretasi sesuai konteks zaman. Aturan-aturan dalam hukum Islam yang kelihatannya tidak sesuai dengan prinsip egaliter dan dan prinsipprinsip lainnya, maka aturan tersebut harus dipahami sesuai dengan konteks realitas sosial yang melingkupinya dan memperhatikan fungsinya sebagai legal counter terhadap aturan-aturan hukum non-egaliter yang berlaku pada masa Jahiliyyah.
\end{abstract}

Kata kunci: pluralisme, hukum Islam

\section{Pendahuluan}

Pluralisme keagamaan (religious pluralism) di Indonesia saat ini masih menjadi wacana yang sensitif dan kontroversial. Apalagi sejak majelis ulama Indonesia (MUI) mengeluarkan fatwa sesat pada sekulerisme, pluralisme, dan liberalisme dalam Musyawarah Nasional pada 26-29 Juli 2005.

Merujuk pada konsep Diana L. Eck, sebagaimana dikutip oleh Biyanto, pluralisme dikatakan berbeda dengan pluralitas atau diversitas. Pluralisme juga bukan sekadar toleransi pasif. Bahkan pluralisme tidak mesti dipahami sebagai relativisme sebagaimana dikemukakan MUI dan para penolak paham tersebut.

Dengan demikian pluralisme meniscayakan adanya kesediaan antarpemeluk agama dan keagamaan untuk berdialog, saling berbicara, dan saling mendengar. Menurut A. Mukti Ali, dialog yang dikembangkan bukan semata dialog teologi, tetapi juga dialog kehidupan, dialog kegiatan sosial, sharing pengalaman keagamaan, dan do'a bersama. Konsepsi pluralisme keagamaan di atas tidak akan dibahas lebih jauh dalam makalah ini. Makalah ini hanya sedikit menjawab tantangan Rektor UIN Sunan Kalijaga di atas, mengenai pentingnya membahas 
pluralisme hukum Islam (Islamic legal pluralism). Makalah ini juga tidak berpretensi menjawab semua persoalan dalam memahami pluralisme hukum Islam. Makalah ini hanya akan sedikit mengambarkan (mendiskripsikan), apa yang dimaksud dengan pluralisme hukum Islam.

\section{Pengertian Pluralisme Hukum}

M. Amin Abdullah mengatakan bahwa ssu pluralisme hukum penting dibahas di tengah jumudnya (bekunya) pemikiran hukum Islam di Indonesia (Kompas, 7 Oktober 2008). Pluralisme hukum secara umum didefinisikan sebagai situasi dimana terdapat dua atau lebih sistem hukum yang berada dalam suatu kehidupan sosial. Pluralisme hukum menurut Hooker sebagaimana dikutip oleh I Nyoman Nurjaya menerangkan suatu situasi di mana dua atau lebih sistem hukum berinteraksi dalam satu kehidupan sosial. Lebih lanjut, F.von Benda-Beckmann memandang pluralisme hukum sebagai suatu kondisi di mana lebih dari satu sistem hukum atau institusi bekerja secara berdampingan dalam aktivitas-aktivitas dan hubungan-hubungan dalam satu kelompok masyarakat. Maka dari itu, pluralisme hukum harus diakui sebagai sebuah realitas masyarakat

Pluralisme hukum adalah sesuatu yang ada di segala situasi, merupakan sesuatu yang berlaku umum dalam kehidupan masyarakat, dimana setiap hukum dan institusi hukum yang berlaku dalam suatu masyarakat tidak tergabung dalam atau bersumber pada satu sistem tetapi bersumber pada tiap aktivitas pengaturan diri sendiri yang ada pada berbagai wilayah sosial yang beragam. Aktivitas tersebut dapat saling mendukung, melengkapi, mengabaikan atau mengacaukan satu dengan yang lain, sehingga "hukum" yang efektif secara nyata dalam masyarakat adalah hasil dari proses kompetisi, interaksi, negosiasi dan isolasi yang bersifat kompleks dan tidak dapat diprediksi

Dalam konteks ini menurut Herlambang dan Steni sebagaimana dikutip oleh Rifai Lubis bahwa pluralisme hukum telah digunakan untuk pertama, menjadi media/lingkungan untuk menyemai dan merawat tata aturan lokal, baik yang telah ada, maupun yang akan dikonstruksi untuk merespons perkembangan kebutuhankebutuhan yang bersifat lokal; kedua, menjadi benteng/tameng bagi komunitas dari intervensi nilai atau norma eksternal yang tidak sejalan dengan cita-cita komunitas, 
dengan mengatakan bahwa dimasyarakat yang bersangkutan telah terdapat tata aturan. Hak komunitas untuk untuk merawat dan menjalankan tata aturan tersebut, mesti dihormati dan difasilitasi oleh nilai-nilai yang datang dari luar lingkungan komunitas yang bersangkutan; dan ketiga, menjadi "energizer" bagi bangkit dan bekerjanya sistem sosial lokal.

Dengan cara kerja yang demikian, bagi aktivis gerakan sosial pembaruan hukum, penggunaan pluralisme hukum, justru ditujukan untuk memfasilitasi hadirnya kembali keadilan bagi komunitas-komunitas marjinal, sekaligus memastikan tetap berlangsungnya penguasaan masyarakat atas sumber daya yang ada. Keadilan yang tentunya didasarkan pada pengetahuan dan pengalaman korban. Bukan keadilan berdasarkan konstruksi institusi pembuat hukum formal, yang bisa dipastikan, karena posisi dan status sosial-politiknya, tidak pernah menjadi korban ketidakadilan dari produk yang diciptakannya sendiri.

Lebih lanjut, pluralisme hukum memberikan penjelasan terhadap kenyataan adanya keteraturan atau tertib sosial (social order) yang sama sekali bukan merupakan bagian dari keteraturan hukum (legal order) yang diproduksi oleh negara

Dengan meminjam kata-kata dari Griffiths legal pluralism is the fact. Legal centralism is a myth, an ideal, a claim, an illusion. Legal pluralism is the name of a social state of affairs and it is a characteristic which can be predicted of a social group. Konsep pluralisme hukum yang dikemukakan Griffiths di atas pada dasarnya dimaksudkan untuk menonjolkan keberadaan dan interaksi sistem-sistem hukum dalam suatu masyarakat, antara hukum negara (state law) dengan sistem hukum rakyat (folk law) dan sistem hukum agama (religious law) dalam suatu kelompok masyarakat

\section{Pengertian Hukum Islam}

Hukum Islam (Islamic Law) merupakan perintah-perintah suci dari Allah SWT yang mengatur seluruh aspek kehidupan setiap Muslim dan meliputi materimateri-materi hukum secara murni serta materi-materi spiritual keagamaan. Melalui penelitian sejarah yang empiris, Joseph Schacht menyebut Islamic Law sebagai ringkasan dari pemikiran Islam, manifestasi way of life Islam yang sangat khas, dan 
bahkan sebagai inti dari Islam itu sendiri. Pernyataan senada juga diungkapkan oleh Anderson, bahwa hukum mencerminkan jiwa bangsa bersangkutan secara lebih jelas dari lembaga apapun. Akan tetapi, fakta-fakta sejarah menunjukkan bahwa hukum Islam lebih merupakan Jurist's Law, Lawyer's Law, Professor's Law atau hukum Fuqaha

Secara umum, hukum Islam berdiri di atas prinsip-prinsip yang harus dipertahankan secara absolut dan universal. Prinsip-prinsip tersebut, sebagaimana dikemukakan oleh Masdar F. Mas'udi, adalah ajaran yang qath'i dan menjadi tolok ukur pemahaman dan penerimaan hukum Islam secara keseluruhan. Prinsip-prinsip tersebut diidentifikasikan oleh Masdar yang antara lain adalah prinsip kebebasan dan pertanggungjawaban individu, prinsip kesetaraan derajat manusia di hadapan Allah, prinsip keadilan, prinsip persamaan manusia di hadapan hukum, prinsip tidak merugikan diri sendiri dan orang lain, prinsip kritik dan kontrol sosial, prinsip menepati janji dan menjunjung tinggi kesepakatan, prinsip tolong menolong untuk kebaikan, prinsip yang kuat melindungi yang lemah, prinsip musyawarah dalam urusan bersama, prinsip kesetaraan suami-istri dalam keluarga, dan prinsip saling memperlakukan dengan ma'ruf antara suami dan istri.

\section{Pluralisme Hukum Islam, Sebuah Pembacaan Awal}

Jika kemudian ada aturan-aturan dalam hukum Islam yang kelihatannya tidak sesuai dengan prinsip egaliter dan dan prinsip-prinsip lainnya, maka aturan tersebut harus dipahami sesuai dengan konteks realitas sosial yang melingkupinya dan memperhatikan fungsinya sebagai legal counter terhadap aturan-aturan hukum non-egaliter yang berlaku pada masa Jahiliyyah.

Sebagai contoh hukum waris yang membagi harta warisan pada laki-laki dan perempuan dengan bagian satu berbanding dua sebagaimana disebutkan di dalam alQur'an, menurut pemahaman yang egaliter, sebagaimana diungkapkan oleh Masdar misalnya, harus dipahami dengan memperhatikan dua hal yang penting. Pertama, dengan memberi bagian warisan kepada perempuan serta mendudukkan laki-laki dan perempuan sama-sama sebagai subyek penerima warisan, maka berarti hukum Islam telah melakukan reformasi yang cukup revolusioner dan radikal terhadap hukum Jahiliyyah yang telah ada sebelumnya, yaitu tidak menjadikan perempuan 
sebagai subyek penerima harta warisan dan bahkan bisa menjadi harta warisan itu sendiri. Kedua, setting sosial ekonomi dalam kehidupan keluarga pada masa munculnya aturan hukum tersebut adalah beban nafkah keluarga ditanggung oleh laki-laki, sehingga pembagian warisan yang membagi laki-laki dengan bagian warisan yang lebih besar daripada bagian warisan perempuan merupakan pembagian yang adil. Dengan begitu, maka aturan-aturan hukum Islam adalah aturan hukum yang memiliki karakter egaliter, tidak rasial, tidak feodal dan tidak patriarkal.

Mengikuti tiga tipologi pembacaan al-Qur'an pada masa kontemporer yang dikaji oleh Sahiron Syamsuddin, kita akan lebih jelas melihat bagaimana sumber hukum utama agama Islam (al-Qur'an) diposisikan dalam menyelesaikan persoalan pemaknaan kitab suci. Pertama, pandangan quasi-obyektivis tradisionalis. Artinya, suatu pandangan bahwa ajaran-ajaran al-Qur'an harus dipahami, ditafsirkan dan diaplikasikan pada masa kini, sebagaimana ia dipahami, ditafsirkan dan diaplikasikan pada situasi, di mana al-Qur'an diturunkan kepada Nabi Muhammad s.a.w, dan disampaikan pada generasi muslim awal. Umat Islam yang mengikuti pandangan ini, seperti Ikhwanul Muslimin di Mesir dan kaum salafi di beberapa negara Islam, berusaha menafsirkan al-Qur'an dengan bantuan berbagai perangkat metodis ilmu tafsir klasik, seperti ilmu asbabun nuzul, ilmu munasabat al-ayat, ilmu tentang muhkam dan mutashabih, dll. Dengan tujuan dapat menguak kembali makna obyektif atau makna asal (objective meaning/original meaning) ayat tertentu. Pandangan ini mempunyai tendensi utama memegani pandangan literal terhadap alQur'an. Ketetapan-ketetapan hukum (juga ketetapan-ketetapan yang lain) yang tertera secara tersurat di dalam al-Qur'an dipandangnya sebagai esensi pesan Tuhan, yang harus diaplikasikan oleh umat Islam di manapun dan kapanpun. Hal ini mengarah pada suatu kenyataan, bahwa tujuan-tujuan pokok atau alasan-alasan yang melatarbelakangi penetapan hukum (maqashid al-shar'iyah) tidak diperlihatkan secara prinsipil. Para ulama yang memegang teguh pandangan ini memang menjelaskan beberapa tujuan hukum yang mungkin merupakan dasar ketetapanketetapan hukum al-Qur'an, namun, penjelasan mereka itu tidak dimaksudkan untuk memberikan penekanan pada tujuan-tujuan penetapan hukum itu sendiri, melainkan bertujuan untuk menunjukkan bahwa ketetapan-ketetapan dalam al-Qur'an itu rasional dan sebaiknya atau seharusnya diaplikasikan dalam kehidupan umat Islam 
sepanjang masa. Singkat kata, apa yang dimaksud dengan moto al-Qur'an shalih li kulli zaman wa makan adalah arti literal dari apa yang tersurat secara jelas dalam alQur'an.

Contoh penfasiran: Q.S. an-Nisa' (4:11) (tentang pembagian harta waris), menurut kelompok ini pembagian 1:2 adalah pesan utama, sehingga aturan ini harus diikuti sepanjang masa dan di segala tempat. Demikian pula dengan penafsiran Q.S. an-Nisa' (4:3) (tentang poligami), pembolehan poligami sebagai pesan inti.

Kedua, pandangan subyektivis. Berbeda dengan pandangan-pandangan tersebut di atas, aliran subyektivis menegaskan bahwa setiap penafsiran sepenuhnya merupakan subyektivitas penafsir. Dan oleh karena itu, kebenaran interpretatif bersifat relatif. Atas dasar ini, setiap generasi mempunyai hak untuk menafsirkan alQur'an seseuai dengan perkembangan ilmu dan pengalaman pada saat al-Qur'an ditafsirkan. Pandangan seperti ini antara lain dianut oleh Muhammad Shahrur (Syahrur; Shahrour). Dia tidak lagi tertarik untuk menelaah makna asal dari sebuah ayat atau kumpulan ayat-ayat. Mufassir modern, menurutnya, seharusnya menafsirkan al-Qur'an sesuai dengan perkembangan ilmu modern, baik ilmu eksakta maupun non-eksakta. Shahrur menegaskan bahwa kebenaran interpretatif terletak pada kesesuaian sebuah penafsiran dengan kebutuhan dan situasi serta perkembangan ilmu pada saat al-Qur'an ditafsirkan. Dia mengatakan misalnya:

Ijtihad itu dipandang benar dan dapat diterima, jika ia sesuai dengan realitas (kehidupan) obyektif. Dengan kata lain, jika 'pembaca' teks memahami realitas obyektif pada saat melakukan 'penafsiran historis'. Pemahaman dan kesesuaian (dengan realitas obyektif) merupakan ukuran yang dapat menentukan apakah sebuah penafsiran itu benar atau salah (Shahrur, 2000: 57)

Jadi, baginya, tak satu penafsiran pun mempunyai kebenaran absolut. Atas dasar ini, penafsiran al-Qur'an pada masa awal Islam hanya merupakan usaha eksegenik awal (al-ihtimal al-awwal), bukan satu-satunya penafsiran yang otoritatif (at-tafsir al-wahid), sehingga kebenarannya bersifat relatif (nisbi), dalam arti hanya sesuai dengan kebutuhan masanya. Dalam hal ini dia berpegang pada adagium : tsabat al-nashsh wa-harakat al-muhtawa (teks al-Qur'an tetap, tetapi kandungannya terus bergerak atau berkembang). Dia memandang bahwa al-Qur'an seakan-akan baru saja diterima oleh kita dari Nabi Muhammad s.a.w. Ide tentang relativitas 
penafsiran ini, menurutnya, diinspirasi oleh 'filsafat proses' yang dikemukakan oleh Whitehead, seorang filosof kontemporer berkebangsaan Inggris.

Contoh, Q.S. an-Nisa' (4:11), penafsiran Shahrur dalam kitabnya al-Kitab wa-l-Qur'an, pembagian warisan 1:2 adalah batas minimal (al-hadd al-adna) bagi anak perempuan dan batas maksimal (al-hadd al-a'la). Penafsirannya dalam buku Nahwa Ushul Jadidah, ayat tersebut ditafsirkan dengan menggunakan teori himpunan dan teori fungsi dalam matematika modern.

Q.S. an-Nisa' (4:3), poligami diperbolehkan dengan syarat yang ditetapkan dalam ayat tersebut dan bisa diaplikasikan sesuai dengan pertimbangan kondisi masyarakat. Istri kedua dan seterusnya harus janda yang mempunyai anak yatim.

Ketiga, pandangan quasi-obyektivis modernis. Pandangan ini memiliki persamaan dengan pandangan quasi obyektivis tradisionalis dalam hal mufasir di masa kini tetap berkewajiban untuk menggali makna asal dengan menggunakandisamping perangkat metodis ilmu tafsir-juga perangkat metodis lain. Seperti informasi tentang konteks sejarah makro dunia Arab saat penurunan wahyu, teoriteori ilmu bahasa dan sastra modern serta hermeneutika. Hanya saja, aliran quasi subyektivis modern yang diantaranya dianut oleh Fazlurrahman dengan konsep double movemen, Muhammad at-Thalibi dengan konsepnya al-tafsir al-maqashidi (Thalibi, 1992: 144) dan Nasr Hamid Abu Zaid dengan konsepnya al-tafsir al-siyaqi (Shahrur, 2000: 56-57), memandang makna asal (bersifat historis) hanya sebagai pijakan awal bagi pembacaan al-Qur'an di masa kini; makna asal literal tidak lagi dipandang sebagai pesan utama al-Qur'an. Bagi mereka, sarjana-sarjana muslim saat ini harus juga memahami makna di balik pesan literal, yang disebut oleh Rahman sebagai rasio legis, dinamakan oleh at-Thalibi dengan maqashid (tujuan-tujuan ayat) atau disebu oleh Abu Zaid dengan maghza (signifikansi ayat). Makna di balik pesan literal inilah yang harus diimplementasikan pada masa kini dan akan datang.

Contoh, Q.S. an-Nisa' (4:11), pembagian 1:2 adalah historis sesuai dengan kondisi masyarakat Arab waktu turunya ayat tersebut. Makna obyektif/historis tidak harus diaplikasikan di sepanjang masa dan tempat. Signifikansi ayat tersebut adalah pemberian hak waris kepada kaum perempuan.

Q.S. an-Nisa' (4:3), pembolehan poligami disesuaikan dengan kondisi sejarah pada masa Nabi. Makna ini boleh ditangguhkan (dilarang). 
Signifikansi/pesan utama ayat tersebut adalah pembebasan kaum perempuan dari hegemoni kaum laki-laki, serta pembumian nilai keadilan.

Guna mendungkung keadaan di atas diperlukan usaha bersama antara fuqaha, sarjana hukum, dan semua kalangan yang masih memedulikan hukum Islam untuk duduk satu meja melakukan dialog. Dengan dialog yang santun dan menghormati pendapat orang lain akan mampu melahirkan corak fiqh yang yang lebih humanis.

Dialog ini kemudian didukung dengan hasil penelitian yang cukup memadai dengan berbagai pisau analisis, salah satunya dengan pendekatan kesejarahan. Proses kesejarahan inilah yang akan menuntun kita menjadi sejarawan-pemikir bukan hanya sejarawan-pemikiran, meminjam istilah Mohammed Arkoun. Sejarawan pemikiran bertugas hanya untuk menggali asal-usul dan perkembangan pemikiran (sejarawan murni), sementara sejarawan-pemikir dimaksudkan sebagai sejarawan yang setelah mendapatkan data-data obyektif, ia bisa juga mengolah data tersebut dengan memakai analisis filosofis. Dengan kata lain, seorang sejarawanpemikir bukan hanya bertutur sejarah pemikiran belaka secara pasif, melainkan juga secara aktif bisa bertutur dalam sejarah (antropologi), agar pandangan yang dihasilkan benar dapat merepresentasikan keinginan masyarakat (Meuleman, 1993: 94).

Pendapat di atas pada dasarnya akan semakin mengokohkan posisi muslim di Indonesia. Artinya, di tengah gamangnya pembahasan amandeman KUHP dan KUH Perdata yang mensyaratkan memasukan unsur hukum Islam di dalamnya, penelitianpenelitian hukum dengan pisau analisis pluralisme hukum akan memberikan kejelasan atau kepastian hukum bagi masyarakat, terutama umat Islam. Umat Islam akan semakin yakin dengan keyakinannya karena ada kepastian hukum. Inilah yang kemudian menjadikan hukum Islam menjadi subyek yang paling penting dalam hukum Islam.

Catatan akhir, pengkajian dan penelitian mengenai pluralisme hukum sebagai bagian dari ilmu antropologi hukum penting kiranya segera dibahas. Artinya, pendekatan baru ini perlu diperkenalkan kepada mahasiswa strata satu (S1) maupun dua (S2). Sehingga penelitian-penelitian keagamaan dalam hukum Islam lebih humanis dan benar-benar mampu merepresentasikan "kegundahan" masyarakat. 
Lebih dari itu, sebagaimana diungkapkan oleh M. Amin Abdullah di atas, pemahaman mengenai pluralisme hukum akan mampu memecahkan kejumudan dalam pemikiran hukum Islam di Indonesia. Wallahu a 'lam.

\section{Daftar Pustaka}

Abdullah, M. Amin, Dinamika Islam Kultural, Pemetaan Atas Wacana Keislaman Kontemporer, Bandung: Mizan, 2000.

Ali, A. Mukti, Ilmu Perbandingan Agama di Indonesia, Yogyakarta: Sunan Kalijaga Press, 1988.

Anderson, J.N.D, Islam Law in the Modern World, New York: New York University Press, 1954.

Andiko, "Legal Pluralism: Sebuah Pisau Analisa", Perkumpulan untuk Pembaruan Hukum yang Berbasiskan Masyarakat\& Ekologis(HuMa).

Biyanto, "Pluralisme, Pengakuan Keragaman yang Inklusif", Jawa Pos, Sabtu, 11 Oktober 2008.

Goitein, S.D, "The Birth-Hour of Muslim Law; an Essay in Exegesis" dalam Jurnal The Muslim World, Vol. L, Hartdford: The Hartdford Seminary Foundation, 1960.

Griffiths, John, "Memahami Pluralisme Hukum: Sebuah Deskripsi Konseptual" dalam Tim HuMa, Pluralisme Hukum: Suatu Pendekatan Interdisiplin, Jakarta: HuMa, 2006.

Lubis, Rifai, "Pluralisme Hukum dalam Pengalaman: Menggugat Kepastian dan Keadilan Sentralisme Hukum”, Makalah disampaikan pada acara Seminar Nasional Pluralisme Hukum Pluralisme Hukum: Perkembangan di Beberapa Negara, Sejarah Pemikirannya di Indonesia dan Pergulatannya dalam 
Gerakan Pembaruan Hukum, pada tanggal 21 November 2006 di Universitas Al Azhar, Jakarta.

Mas'udi, Masdar Farid, Islam dan Hak-hak Reproduksi Perempuan: Dialog Fiqh Pemberdayaan, Bandung: Mizan, 1997.

Meuleman, Johan H, "Nalar Islami dan Nalar Modern: Memperkenalkan Pemikiran Arkoun”, dalam Jurnal Ulumul Qur'an, Nomor 4 Vol. IV. 1993.

Minhaji, Akh, "Supremasi Hukum dalam Masyarakat Madani (Perspektif Sejarah Hukum Islam), dalam Unisia, No. 41/XXII/2000.

, "Wacana Islam tentang Negara dan Pemerintahan (Perspektif Normatif-Empiris), Sebuah Pengantar”, Pengantar, Kamaruzzaman, Relasi Islam dan Negara Perspektif Modernisme \& Fundamentalisme, Magelang: IndonesiaTera, 2000.

, "Hukum Islam di Mata Sarjana Barat: Kajian Bibliografi terhadap Tesis Joseph Schacht dan Beberapa Tanggapan Terhadapnya", dalam Sudarnoto Abdul Hakim, dkk (peny), Islam Berbagai Perspektif, Yogyakarta: Lembaga Penterjemah dan Penulis Muslim Indonesia, 1995.

Nurjaya, I Nyoman, “Antropologi Hukum: Perkembangan Tema Kajian, Metodologi, dan Model Penggunaannya untuk Memahami Fenomena Hukum di Indonesia", Makalah Seminar dan Pelatihan Pluralisme Hukum, yang diselenggarakan Perkumpulan untuk Pembaruan Hukum Berbasis Masyarakat dan Ekologis (HuMa), pada tanggal 28-30 Agustus 2003 di Hotel Rudian, Cisarua, Bogor.

Schacht, Joseph, An Introduction to Islamic Law, Cet. II (Oxford: Oxford University Press, 1964. 
Syamsuddin, Sahiron Disertasi, "Muhammad Shahrurs Koranhermeneutik und die Debatte um sie bei muslimischen Autoren", Otto-Friedrich: Universitat Bamberg, 2006. Ditulis juga dalam Sortcouse Filsafat, "Tipologi dan Proyeksi Pemikiran Tafsir Kontemporer: Studi Atas Ide Dasar Hermeneutika Qur'an”, UIN Sunan Kalijaga, 2 September 2008.

"Pluralisme Hukum Harus Diakui", www.hukumonline.com, 2 Juli 2006, akses 9 Oktober 2008.

“UIN Sunan Kalijaga Mendukung Pluralisme”, Kompas, Selasa, 7 Oktober 2008. 